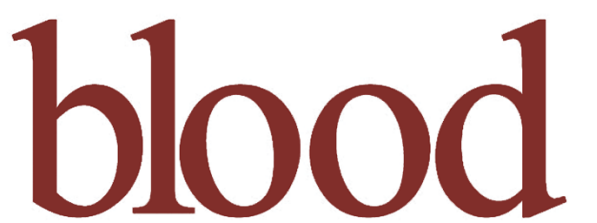

Prepublished online Jan 18, 2008;

doi:10.1182/blood-2007-08-107755

\title{
Cognate CD4+ T cell-dendritic cell interactions induce migration of immature dendritic cell through dissolution of their podosomes
}

Cinzia Nobile, Marianne Lind, Francesc Miro, Karine Chemin, Marie Tourret, Giovanni Occhipinti, Stephanie Dogniaux, Sebastian Amigorena and Claire Hivroz

Information about reproducing this article in parts or in its entirety may be found online at: http://bloodjournal.hematologylibrary.org/misc/rights.dtl\#repub_requests

Information about ordering reprints may be found online at:

http://bloodjournal.hematologylibrary.org/misc/rights.dtl\#reprints

Information about subscriptions and ASH membership may be found online at:

http://bloodjournal.hematologylibrary.org/subscriptions/index.dtl

Blood (print ISSN 0006-4971, online ISSN 1528-0020), is published semimonthly by the American Society of Hematology, 1900 M St, NW, Suite 200, Washington DC 20036.

Copyright 2007 by The American Society of Hematology; all rights reserved.

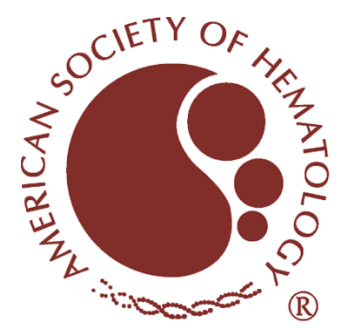


Cognate CD4+ T cell-dendritic cell interactions induce migration of immature dendritic cell through dissolution of their podosomes

Short title: T cells induce dendritic cell migration

Cinzia Nobile ${ }^{1,2}$, Marianne Lind ${ }^{1,2}$, Francesc Miro ${ }^{1,2}$, Karine Chemin ${ }^{1,2}$, Marie Tourret ${ }^{1,2}$, Giovanni Occhipinti $^{3}$, Stéphanie Dogniaux ${ }^{1,2}$, Sebastian Amigorena ${ }^{1,2}$ and Claire Hivroz ${ }^{1,2,4}$.

${ }^{1}$ Institut Curie, Centre de Recherche, Pavillon Pasteur, 26 Rue d'ULM, Paris, F-75248, France.

${ }^{2}$ INSERM, Unité 653, Immunité et Cancer, Paris, F-75248, France.

${ }^{3}$ Caltech, Seismological Laboratory, 1200 E California blvd., 91125 Pasadena, CA, USA

${ }^{4}$ Corresponding author: claire.hivroz@curie.fr 


\section{ABSTRACT :}

Dendritic cells (DC) control T cell-based immunity. To do so they need to mature and migrate to sites of $\mathrm{T}$ cell priming. We have previously shown that cognate interactions of human $\mathrm{CD}^{+} \mathrm{T}$ cells with DC induce DC maturation. We show here that $\mathrm{CC}$ chemokines produced during antigen-specific T-DC interactions also induce strong morphological modifications and migration of immature DC. These modifications are required for efficient $\mathrm{T}$ cell activation. Moreover, we show that CC chemokines produced during antigen-specific DC-T cell interactions induce the dissolution of structures involved in cell motility and present on immature DC, i.e. podosomes. We thus propose a model in which chemokines secreted during Ag-specific contact between $\mathrm{T}$ cells and DC induce disassembly of interacting and neighboring immature DC podosomes, leading to recruitment of more immature DC towards sites of antigenic stimulation and to amplification of $\mathrm{T}$ cell responses. 


\section{INTRODUCTION}

Dendritic cells (DC) are professional antigen presenting cells with the unique property of inducing priming and differentiation of naïve $\mathrm{CD}^{+}$and $\mathrm{CD}^{+} \mathrm{T}$ cells into helper and cytotoxic effectors, respectively. Their efficiency is due to their unique ability to process antigen, express costimulatory molecules, secrete cytokines and migrate to the appropriate sites, in tissues or lymphoid organs, to prime T cells ${ }^{1}$.

$\mathrm{CD}^{+}$helper $\mathrm{T}$ cells have been shown to promote the quality of $\mathrm{T}$ cell responses ${ }^{2,3}$. There is ample evidence that this helper activity is due to the ability of $\mathrm{CD}^{+} \mathrm{T}$ cells to act directly on DC in an antigen-dependent manner. Indeed, experiments conducted both in murine and human models have shown that interaction between CD40 and CD40L ${ }^{4-7}$, expressed respectively by DC and activated T cells, as well as T cell-derived cytokines such as IFN- $\gamma$ and TNF- $\alpha$ modify the DC properties by inducing expression of costimulatory molecules and IL-12 ${ }^{8-10}$. This $\mathrm{T}$ cell-induced modification of DC has been called "education" 3 or "licensing" 11 .

As stated above, expression by DC of costimulatory molecules and secretion of cytokines is not sufficient to induce $\mathrm{T}$ cell activation. $\mathrm{DC}$ also need to be recruited to the appropriate sites in order to induce $\mathrm{T}$ cell responses. This implies migration of maturing $\mathrm{DC}$ from peripheral tissues towards the draining lymph nodes through lymphatic vessels (reviewed in ${ }^{12}$ ) as well as mobilization of resident DC of the lymphoid organs to the T cell zones ${ }^{13}$ or recruitment of DC, mostly immature, to the peripheral inflammatory tissues ${ }^{14,15}$.

We have previously shown in a human model that antigen specific interactions of $\mathrm{CD}^{+} \mathrm{T}$ cells with immature DC induce activation of DC leading to expression of co-stimulatory molecules and production of IL-12 ${ }^{10}$. We show herein that $\mathrm{CC}$ chemokines produced during these antigen specific interactions between $\mathrm{CD}^{+} \mathrm{T}$ cells and $\mathrm{DC}$ also induce specific attraction of immature DC to the site of interaction. This induced chemotaxis of immature DC 
is accompanied by a complete remodelling of the DC actin cytoskeleton, which leads to dissolution of adhesion structures known as podosomes ${ }^{16}$ and to a drastic change of the morphology of DC. Actin cytoskeleton remodelling also depends on chemokines suggesting that the disappearance of podosomes and the acquisition of migratory ability by DC are linked.

\section{MATERIALS AND METHODS}

\section{Reagents and antibody}

Medium: RPMI 1640 Glutamax, 1\% pyruvate, $100 \mathrm{U} / \mathrm{ml}$ penicillin, $100 \mu \mathrm{g} / \mathrm{ml}$ streptomycin (Invitrogen), and 10\% FCS (Biowest). Recombinant human IL-4 and GM-CSF were from BRUCELLS. Recombinant bacterial superantigens were from Toxin Technology. PTX and CCI were from Sigma-Aldrich, chemokines (CCL3, CCL4, CCL5, CXCL8) from R\&D system. Mouse mAbs against human CD4, CD69, CD40, CD80, CD83, CD86 and isotypic controls coupled to fluorochromes were from BD Bioscience. Alexa 488-conjugated $F\left(a b^{\prime}\right) 2$ anti-mouse Abs, CFSE (Carboxy-fluorescein diacetate succinimidyl ester), DiD (Vybrant DiD cell-labeling solution) and phalloidin coupled to Alexa 543 were from Molecular Probes.

\section{Cells}

DC were generated from human monocytes of healthy donors as previously described ${ }^{10}$. Briefly, anti-CD $14^{+}$monocytes were sorted positively using magnetic microbeads (Miltenyi Biotec). Monocytes were cultured 5 days in medium supplemented with $100 \mathrm{ng} / \mathrm{ml} \mathrm{GM-CSF}$ and $50 \mathrm{ng} / \mathrm{ml} \mathrm{IL-4}$. This protocol lead to 98 to $99 \%$ of $\mathrm{CD}^{+}{ }^{+} / \mathrm{CD} 14^{-} \mathrm{DC}$ presenting an immature phenotype ${ }^{10} \cdot \mathrm{CD} 4^{+} \mathrm{T}$ cells were negatively selected from PBMCs, after depletion of $\mathrm{CD}_{14}{ }^{+}$cells, using the $\mathrm{T}$ cell isolation kit II from Miltenyi Biotec. Sorted $\mathrm{CD}^{+} \mathrm{T}$ cells were $97-99 \% \mathrm{CD}^{+} / \mathrm{CD}^{+}$. 


\section{Preparation of active supernatants}

$1.5 \times 10^{5} \mathrm{DC}$ were co-cultured with $3 \times 10^{5} \mathrm{~T}$ cells in 24 -well plates in the presence or absence of superantigen. Supernatants were collected and filtered 24 hours later.

\section{T cell activation assay and flow cytometry analysis}

DC were left untreated or pre-treated with $200 \mathrm{ng} / \mathrm{ml}$ PTX for 2 hours, extensively washed and co-cultured overnight with $\mathrm{CD}^{+} \mathrm{T}$ cells in flat or round -bottom 96-well plates.

Cells were stained with APC-coupled anti-CD69 and FITC-coupled anti-CD4 mAbs at $4^{\circ} \mathrm{C}$ for 30 min. Samples were analyzed on a FACSCalibur using the CellQuest software (BD Biosciences).

\section{Migration experiments}

Chemotaxis of DC was measured by migration through a polycarbonate filter of $5 \mu \mathrm{m}$ pore size in transwell chambers (Corning Costar). $2 \times 10^{5}$ DC $(150 \mu 1)$ were seeded in the upper chamber, control medium or stimuli $(250 \mu 1$ of supernatants or recombinant chemokines at $100 \mathrm{ng} / \mathrm{ml}$ ) were added into the lower chamber. In some experiments, DC were pretreated with $200 \mathrm{ng} / \mathrm{ml} \mathrm{PTX} \mathrm{(2} \mathrm{hours} \mathrm{at} 37^{\circ} \mathrm{C}$ ) or CCI (20 minutes, room temperature) before the assay. After 2 hours at $37^{\circ} \mathrm{C}, 10^{5}$ beads (Beckman Coulter) were added to all lower wells and the number of cells for a given number of beads counted by flow cytometry. Values are given as percentage of cells in the lower well $\pm \mathrm{SD}$.

For the Dunn chamber analysis, both annular wells of the Dunn chamber were filled with control medium and the poly-L-lysin coated coverslip seeded with DC was inverted onto the chamber. A narrow filling slit at one edge was left to access the outer well. To set up a chemotactic gradient, medium was drained from the outer well and replaced with medium containing the chemoattractant. The slit was sealed with nail polish ${ }^{17}$. 
Cells were left for 20 to $30 \mathrm{~min}$ in the Dunn chamber before being visualized with a Leica DMI $6000 \mathrm{~B}$ under and 10X phase contrast objectives. Images were captured at 1 minute intervals and analyzed with Metamorph (Universal Imaging) software. Average rates of cell movement were calculated based on the total movement of cell centroid over the time of observation.

Directionality of cell movement was analyzed using scatter diagrams of cell displacement. The diagrams are oriented so that the position of the outer well of the chamber is vertically upwards (y direction). Each line represents the trajectory of one cell during the recording period (90 minutes) where the starting point of the migration is fixed at the intersection of the two axes.

\section{Cytokine detection in the supernatant}

Chemokine secretion was measured in the supernatants by cytometric bead array (BD Biosciences).

\section{Flow cytometric analysis of chemokine production.}

DC were co-cultured overnight with $\mathrm{CD}^{+} \mathrm{T}$ cells in flat-bottom 96-well plates. Cells were then stained with APC-coupled anti-CD4 and Cy-Chrome-coupled anti-CD1a mAbs (BD, Biosciences). After surface labeling, cells were fixed, permeabilized, and stained for intracellular cytokine production with PE-coupled anti-CCL3, or anti-CCL 5 or FITC-coupled anti-CCL4 (R\&D Systems). Isotypic controls were used as negative controls. Samples were analyzed on a FACSCalibur (BD Biosciences).

\section{Video imaging}

Videomicroscopy was performed using a Leica DM IRBE epifluorescence microscope 
equipped with a x63, 1.32 numerical aperture objective, a cooled charge-coupled device camera (MicroMax, Princeton Instruments from movies 3, 4; Coolsnap EZ, Photometrics for movies 1, 2). Poly-L-lysin coverslips covered with DC were placed into a chamber on the microscope at $37^{\circ} \mathrm{C}$ in a $5 \% \mathrm{CO} 2$ atmosphere. At time $0, \mathrm{~T}$ cells were added, and images were recorded every 3 minutes for 5 hours. Data acquisition and analysis were done with MetaMorph software (Universal Imaging).

\section{Confocal microscopy}

DC and T cells were co-cultured on coverslips. In some experiments, cells were stained with CFSE or DiD before culture according to manufacturer's instructions.

After co-cultures, cells were fixed with 3\% paraformaldehyde (Carlo Erba) and incubated in PBS glycine $(10 \mathrm{mM})$ to quench free aldehyde groups. Cells were then permeabilized with $0.1 \%$ Triton, stained first with anti-vinculin Ab (Sigma) and then with Alexa 488-conjugated F(ab')2 anti-mouse Ig. F-actin was visualized using Alexa 543-conjugated phalloidin. Coverslips were mounted onto glass slides using Fluoromount-G (Southern Biotechnology Associates). Green and red fluorescence were acquired sequentially to prevent leakage of fluorescence from one channel into another.

Images were collected using a Leica TCS SP2 confocal scanning microscope equipped with a x63, 1.4 numerical aperture oil immersion objective. All quantifications were performed blindly on 8-bit images using MetaMorph software.

\section{RESULTS}

Antigen specific contacts between $\mathrm{CD4}^{+} \mathrm{T}$ cells and DC induce DC mobility and recruitment towards the sites of DC-T cell interaction.

We followed by time-lapse videomicroscopy the first hours of interaction between human immature DC and $\mathrm{CD}^{+} \mathrm{T}$ lymphocytes. Immature DC were pre-incubated with a cocktail of 
superantigens (TSST1+SEE+SEA+SEC+SED) and plated on glass coverslips. $\mathrm{CD}^{+} \mathrm{T}$ cells were then added and every 3 minutes a series of 4 xy planes contrast phase images was acquired for 5 hours. In the presence of $\mathrm{CD}^{+} \mathrm{T}$ cells alone, or superantigens alone, DC neither changed their morphology nor became mobile (Fig. 1 A and movies 1, 2). Moreover, as previously described ${ }^{18}$, DC established few interactions with $\mathrm{T}$ cells in the absence of antigenic stimulation (Fig. $1 \mathrm{~A}$, movie 1). In sharp contrast, in the presence of both $\mathrm{T}$ cells and superantigens, immature DC became mobile, as shown by movies and quantification of the images (Fig. $1 \mathrm{~A}$ and movie 3). This DC mobility was accompanied, after 2-3 hours of interaction with $\mathrm{CD} 4^{+} \mathrm{T}$ cells, by striking morphological changes of the $\mathrm{DC}$, which acquired an elongated shape, extending and retracting long dendrites. Activated DC established contacts with $\mathrm{CD} 4^{+} \mathrm{T}$ cells but also with other $\mathrm{DC}$, forming dynamic clusters of $\mathrm{CD} 4^{+} \mathrm{T}$ cells and DC.

These results show that antigen-specific interactions between $\mathrm{CD} 4^{+} \mathrm{T}$ cells and $\mathrm{DC}$ induce mobility, morphological changes and clustering of DC.

We then tested if the acquired DC mobility support their attraction to the site of ongoing DCT cell interactions.

To do so, we designed an experiment to visualize the recruitment of immature DC to the sites of superantigen-specific DC-CD4 ${ }^{+} \mathrm{T}$ cell interactions. DC preparation were separated in two, one population was stained with the fluorescent lipid DiD and pulsed or not with TSST1 and the other was CFSE-labeled and was not exposed to superantigen. After extensive washing, both populations were seeded on coverslips. $\mathrm{CD}^{+} \mathrm{T}$ cells were then added. Six hours later, coverslips were analyzed by confocal microscopy. Image quantification showed that in the absence of antigen about $10 \%$ of DiD-labeled DC were in contact with CFSE-labeled DC, whereas in the presence of superantigen, the number of DiD-DC/CFSE-DC interactions was significantly increased (to $31 \%$, Fig. 1B,C). These results show that neighboring immature 
DC, which did not directly interact with T cells, are recruited to sites of antigen-specific DC$\mathrm{CD}^{+} \mathrm{T}$ cell interactions.

\section{Chemokines produced during superantigen specific DC-CD4 ${ }^{+} \mathrm{T}$ cell interactions induce} chemotaxis of immature DC.

We then asked if soluble factors produced during superantigen induced $\mathrm{DC}-\mathrm{CD} 4^{+} \mathrm{T}$ cell interactions were sufficient to trigger DC mobility and morphological changes. Immature DC were exposed to supernatants from co-cultures of $\mathrm{DC}+\mathrm{CD}^{+} \mathrm{T}$ cells + superantigens and followed by videomicroscopy. As shown in Fig. 2A and movie 4, DC became rapidly mobile and acquired an elongated morphology. This behavior was similar to that observed in the presence of T cells.

We next performed experiments to test if the mobility induced by "active" supernatants was due to chemotaxis (directional movement of cells) or chemokinesis (random cell movement) using a Dunn chemotaxis chamber. This system allows to study the behavior of cells subjected to linear gradient of chemoattractants ${ }^{17}$. Immature DC were exposed to gradients of "active" supernatants in the Dunn chamber and imaged by time-lapse videomicroscopy under phase contrast. Migration tracks of the DC were then quantitatively analyzed with a program developed in Matlab. Figure 2B shows cell trajectories from one representative experiment and direction of the gradient is represented by black lines (the gradient is radial, because of the geometry of the chamber). In figure $2 \mathrm{D}$, the same trajectories are represented in a scatter diagram, with the gradient directed vertically upwards (y).

We calculated the percentage of migrating immature DC, which ended up within a $120^{\circ}$ arc facing the supernatant source. For totally random migration, we would expect to find $33 \%$ of the cells in this region. In contrast, when DC were exposed to a gradient of "active" 
supernatant, $62.6 \% \pm 2.3 \%$ of the DC were found within the $120^{\circ}$ arc after 90 minutes of migration, showing a directional migration of DC towards the supernatant source.

We further characterized the dynamic parameters of $\mathrm{T}$ cell-dependent $\mathrm{DC}$ migration by measuring the mean velocity of the DC in the Dunn chamber. In Fig. $2 \mathrm{C}$, the radial and the horizontal velocity are plotted as a function of time. The radial velocity ( Vr, component of the mean velocity along the gradient), is positive over time, and reaches $0.5 \mu \mathrm{m} / \mathrm{min}$. In contrast, the values of the horizontal velocity (Vh, component perpendicular to the gradient), oscillate in a small range around zero, indicating that the horizontal cell displacement is random and limited. Control supernatants prepared from DC co-cultured overnight with $\mathrm{T}$ cells in the absence of superantigen did not induce any chemotaxis of DC (Fig. 2 D, middle panel).

We then used Bordetella pertussis toxin (PTX), an inhibitor of Gai protein-coupled receptors, which blocks all Gai coupled chemokine-receptors, to test the involvement of chemokines. DC were pre-treated with $200 \mathrm{ng} / \mathrm{ml}$ PTX for $2 \mathrm{~h}$, and extensively washed before imaging their migration in the Dunn chamber. As shown in Fig. 2D, right panel, PTX pre-treatment of DC inhibited chemotaxis induced by "active supernatants".

To confirm that soluble factors secreted during T-DC contacts could promote immature DC migration, we performed transwell chemotaxis assays ${ }^{19}$. Medium or supernatants from different co-cultures were placed in the lower chamber of the transwell system, and immature DC were added to the upper chamber. As presented in Fig. 2E, "active" supernatants induced significant migration of immature DC to the lower chamber, whereas supernatants from cocultures of $\mathrm{DC}+\mathrm{CD}^{+} \mathrm{T}$ cells or of $\mathrm{DC}+$ superantigens alone did not. PTX treatment completely abrogated the "active" supernatant induced DC migration, confirming the results obtained in the Dunn chamber (Fig. 2E). Of note, mature DC obtained by overnight LPS treatment did not migrate towards "active" supernatants (Fig. 2E), whereas as previously 
shown ${ }^{20}$ they migrated towards CCL19 and CCL21 (data not shown), showing that "active" supernatants specifically induced the migration of immature DC.

Altogether, these results demonstrate that chemokines produced during superantigen-specific interaction of $\mathrm{CD}^{+} \mathrm{T}$ cells with DC induce chemotaxis in immature DC, supporting the recruitment of fresh immature DC towards the site of T cell-DC specific interaction.

\section{CC chemokines produced by DC-CD4 ${ }^{+} \mathrm{T}$ cell conjugates induce migration of immature DC.}

We then studied which chemokines were produced in supernatants of $\mathrm{CD} 4^{+} \mathrm{T}$ cells cocultured with DC or DC pulsed with TSST1, by cytometric beads arrays. As shown in Fig. 3A, the following chemokines were secreted in the co-cultures of DC and T cells: CXCL8, CXCL9, CXCL10, CCL2, CCL3, CCL4, CCL5. Most of these chemokines were secreted only in the presence of superantigen.

To better characterize which chemokines were involved in DC migration, we used vCCI (viral CC chemokine inhibitor), a viral component that specifically inhibits chemokine receptors belonging to the CC family ${ }^{21,22}$. As expected, CCI inhibited DC migration towards CCL5, but not towards CXCL12 (supplemental Fig. 1). Pre-treatment of DC with CCI inhibited dose-dependently DC migration towards "active supernatants" (Fig. 3B) showing that CC-chemokines are involved in the migration of immature DC.

We thus tested the CC chemokines present in the "active" supernatants for their ability to induce immature DC migration. As shown in Fig. 3C, CCL3, CCL4 and CCL5 induced migration of immature DC in the transwell assay.

We then characterized the cell type(s) that produce(s) these $3 \mathrm{CC}$ chemokines. Intracellular chemokine stainings were performed on $\mathrm{CD}^{+} \mathrm{T}$ cells and $\mathrm{DC}$ co-cultured overnight with 
TSST1. As shown in Fig. 4, both DC and T cells produced CCL3 and CCL4, whereas CCL5 was only detected in T cells.

Altogether, these results demonstrate that CC-chemokines produced during antigenic stimulation by both $\mathrm{CD} 4^{+} \mathrm{T}$ cells and DC induce migration of immature DC.

\section{DC responses to chemokines enhance $T$ cell activation.}

We then tested if DC responses to chemokines produced during superantigen induced interaction of $\mathrm{CD}^{+} \mathrm{T}$ cells with DC would influence $\mathrm{T}$ cell responses in return. To do so we cultured overnight $\mathrm{CD}^{+} \mathrm{T}$ cells together with untreated or PTX-pre-treated DC at different ratios in the presence of TSST1. We then followed CD69 expression by T cells (Fig. 5 A, B). When DC were pre-treated with PTX, the percentages of activated $\mathrm{CD}^{+} \mathrm{T}$ cells were significantly lower than the percentages obtained with untreated DC, for DC/T cell ratios < $1 / 2$, indicating that $\mathrm{DC}$ response to chemokines increases $\mathrm{T}$ cell activation. In contrast, for $\mathrm{DC} / \mathrm{T}$ ratio $>1 / 2$, PTX treatment of $\mathrm{DC}$ had not significant effects, suggesting that DC response to chemokines is less critical at high cell concentration.

To confirm our interpretation, we performed similar experiments in round bottom wells, wherein contacts between cells are forced by the geometry of the well. Under these conditions, PTX pre-treatment of DC did not affect T cell activation.

We have previously shown that DC cocultured with $\mathrm{CD}^{+} \mathrm{T}$ cells and superantigen expressed higher amount of CD40, CD80, CD83 and CD86 ${ }^{10}$. This enhanced expression of costimulatory molecules may influence $\mathrm{T}$ cell activation. We thus tested if PTX pretreatment of DC inhibited the T cell driven DC maturation. As shown in Fig. 5 C, PTX treatment did not inhibit DC maturation, demonstrating first that PTX does not grossly perturb DC function and second that the inefficiency of PTX pretreated DC to activate T cells is not due to a lesser ability to mature. 
Since T cells are highly sensitive to PTX, we controlled that PTX-treated DC did not release PTX in the supernatants, which could directly affect $\mathrm{T}$ cell activation. We thus added overnight supernatants from PTX-pretreated DC to co-cultures of untreated $\mathrm{DC}+\mathrm{CD} 4^{+} \mathrm{T}$ cells+TSST1. These supernatants did not inhibit T cell activation (Fig. 5B grey histograms), showing that PTX was not released in the medium. We also tested if direct contact of PTXpre-treated DC with T cells could affect $\mathrm{T}$ cell migration. PTX pre-treated DC were thus added to the upper well of a transwell together with $\mathrm{T}$ cells and migration towards CXCL12, which has been shown to be PTX sensitive ${ }^{23}$, was measured after $4 \mathrm{~h} 30$. T cell migration towards CXCL12 was not affected by PTX treated DC (Fig. 5D).

Overall our results strongly suggest that chemokine-induced DC modification plays a role in $\mathrm{T}$ cell activation.

\section{The actin cytoskeleton of immature DC is modified by cognate interaction with $\mathrm{CD}^{+} \mathrm{T}$} cells, and this depends on chemokines.

As shown in Fig. 1 and movies 3 and 4, the T cell-induced mobility of DC was accompanied by striking morphological changes of the DC. To further characterize these changes and gain some insights into the mechanisms involved in mobility of immature DC, we studied the modifications of the DC cytoskeleton induced by $\mathrm{CD}^{+} \mathrm{T}$ cells. Since podosomes have been involved in DC mobility ${ }^{24,25}$, we followed these structures in DC exposed to CD4 ${ }^{+} \mathrm{T}$ cells in the presence or absence of superantigen. When plated on glass coverslips, most immature DC presented the characteristic podosomes, composed of an actin core surrounded by vinculin, on their ventral face $(80 \%$, mean of 4 independent experiments, Fig. 6 A). The percentage of DC presenting podosomes drastically decreased from $80 \%$ to $20 \%$ in DC exposed to antigen specific interaction with $\mathrm{CD} 4^{+} \mathrm{T}$ cells. Moreover, when exposed to $\mathrm{T}$ cells in the presence of superantigen, DC showed an organization of the polymerized actin in filaments and actin 
enrichment at the contact with $\mathrm{T}$ cells (Fig. 6A).

We then studied the cytoskeleton of immature DC treated for 6 hours with "active" supernatants. As shown in Fig. 7A and quantified in 7B, the percentage of DC presenting podosomes was drastically reduced in DC submitted to "active" supernatants (28\% vs $75 \%)$. We then examined the role of chemokines on this striking remodelling of the actin cytoskeleton. As shown in Fig. 6 and 7, pre-treatment of DC with PTX inhibited podosomes dissolution induced by T cells (Fig 6 A, B) or "active" supernatants (Fig.7 A, B), strongly suggesting that chemokines are involved in the modifications of DC cytoskeleton induced by T cells. To confirm the role of chemokines in these modifications, we treated immature DC with several CC-chemokines and studied the modification of the cytoskeleton. As shown in Fig. 7A and quantified in Fig. 7C, CCL3 and CCL4 induced podosome dissolution and morphological changes in immature DC that were very similar to the modifications observed with the "active" supernatants. In contrast, CXCL8, which binds CXCR1 expressed by immature DC (data not shown), did not significantly decrease the number of DC presenting with podosomes (Fig. 7C).

Some chemokines have been shown to induce DC maturation ${ }^{26-28}$ and DC maturation has been shown to induce podosome dissolution ${ }^{25,29}$. We thus tested if CCL3 and CCL4, which induced podosomes dissolution (Fig. 7A and 7C), also induced DC maturation. As shown in Fig. 7D, no increase of CD86, CD83, CD80 and CD40 expression was observed, although as shown in Fig. 5C "active" supernatants did induce increased expression of these markers. These results show that podosome disassembly induced by $\mathrm{CC}$ chemokines does not require DC maturation.

Altogether, these results demonstrate that chemokines produced during antigen-specific interaction between $\mathrm{CD}^{+} \mathrm{T}$ cells and $\mathrm{DC}$ induce actin cytoskeleton remodelling in immature DC, leading to podosome dissolution. 


\section{DISCUSSION}

$\mathrm{DC}$ are key cells in the regulation of $\mathrm{T}$ cell responses. Their efficiency depends on their state of activation, which regulates DC ability to process antigen and to express costimulatory molecules and cytokines ${ }^{1}$. Activation of DC also controls DC migration to the appropriate sites, in tissues or lymphoid organs, wherein they prime $\mathrm{T}$ cells ${ }^{30,31} \cdot \mathrm{CD}^{+} \mathrm{T}$ cell dependent signals have been shown to play a crucial role in DC activation by inducing their licensing to prime CTL or their ability to polarize $\mathrm{T}_{\mathrm{H}}$ cell responses (reviewed in ${ }^{32,33}$ ). $\mathrm{CD}^{+} \mathrm{T}$ celldependent signals induce expression by DC of co-stimulatory markers as well as production of cytokines ${ }^{8-10}$. Regulated migration of DC, implying both migration of DC from the periphery to the $\mathrm{T}$ cell zones of lymphoid organs and migration inside the tissues or lymphoid organs, is central to the induction of physiological immune responses and probably to the maintenance of tolerance ${ }^{34,35}$. We thus addressed the question of the potential modulation by human $\mathrm{CD}^{+} \mathrm{T}$ cells of DC migratory ability.

We show herein that $\mathrm{CC}$ chemokines produced at sites of $\mathrm{CD}^{+} \mathrm{T}$ cell-DC interaction induce recruitment of immature DC and formation of DC clusters at these sites. Some of these CC chemokines are produced both by DC and $\mathrm{CD}^{+} \mathrm{T}$ cells (Fig. 4), suggesting that both cell types contribute to the attraction of immature DC to the site of interaction.

Since the chemokine receptors CCR1, CCR2, CCR3, CCR5 and CCR6 are expressed by immature DC ${ }^{36,37}$, they may be involved in the chemotaxis we report herein. CCR6 can be excluded since its ligand CCL20 did not induce migration of immature DC (data not shown). The role of CCR7 can also be excluded since, as reported by others ${ }^{37}$, the immature DC we used in this study did not express any mRNA for CCR7, even $4 \mathrm{~h}$ after exposure to the supernatants and did not migrate towards CCL19 or CCL21 (data not shown). It is worth noting that the chemokines present in our conditioned supernatants did not induce any 
migration of LPS-matured DC (Fig. 2E), showing that chemokines produced during antigen specific interaction of DC with $\mathrm{CD}^{+} \mathrm{T}$ cells specifically induced mobility of immature DC. Time lapse and confocal microscopy images of DC, that have been interacting for 6 to $18 \mathrm{~h}$ with $\mathrm{T}$ cells in the presence of superantigens, show striking changes of the DC morphology, which correlated with the acquisition of their migratory ability. In these conditions, 25 to $30 \%$ of the immature DC elongated, changing from a roundish shape of $10-15 \mu \mathrm{m}$ in diameter to a "neuron-like" shape of 50-80 $\mu \mathrm{m}$ in length. These modifications were also CC chemokinedependent and were not observed when immature DC were exposed to LPS or poly IC (data not shown) although these TLR ligands induced non-polarized extension of thin transient dendrites around the cellular body of DC. These elongated DC established contact with both $\mathrm{CD}^{+} \mathrm{T}$ cells and other DC (Fig. 1, 6 and 7) and tended to form a network of interdigitating DC after 4 to $6 \mathrm{~h}$ of antigen specific contact with T cells. This chemokine-induced DC-DC interaction may favor the transfer of material between DC, which has recently been shown to amplify T cell responses ${ }^{38}$.

Morphological changes observed in immature DC were accompanied by striking modifications of the actin cytoskeleton. As previously reported ${ }^{29,39}$, the majority of immature DC displayed big clusters of podosomes on their ventral face. When co-cultured with $\mathrm{CD} 4^{+} \mathrm{T}$ cell and superantigen or with "active supernatants", DC showed actin filaments along the plasma membrane, as well as polymerized actin-rich "cups" in the contact zones with T cells, but only sparse podosomes on both ends (Fig. 6 and 7). Podosomes are highly dynamic structures consisting of a dense actin core surrounded by a ring of vinculin found on several cells from the myeloid lineage ${ }^{40}$. These structures have been shown to be involved in cell migration, tissue invasiveness ${ }^{41}$ and diapedesis ${ }^{42}$. We show herein a strong inverse correlation between the presence of podosomes and DC migration. Indeed, as reported by 
others, podosomes expressed by immature DC may restrict their speed of migration by increasing their interaction with the substrate ${ }^{25}$.

In our study, we show for the first time that chemokines, which induce DC migration, also induce podosome disassembly. Several maturation-inducing agents such as LPS ${ }^{29,43}$, PGE2 and TNF- $\alpha^{25}$, have been shown to induce podosome dissolution suggesting that this dissolution is an integral part of the DC maturation process. Results reported herein suggest that these two phenomena can be dissociated since PTX pretreatment of DC blocks podosome dissolution but does not affect phenotypic DC maturation (Fig. 5C), whereas CC chemokines induce podosome dissolution without inducing DC maturation (Fig. 7D).

Yet, the resulting redistribution of the actin pool trapped in podosomes towards different sites may be required for mature DC functions, such as the maturation of endosomes ${ }^{44}$ or the recruitment of transmembrane receptors to the contact zone with interacting T lymphocytes ${ }^{45}$. Chemokines can enhance and modulate T-cell activation by DC in more than one fashion. DC presentation of cognate antigen to $\mathrm{CD} 4^{+} \mathrm{T}$ cells in lymph nodes induces the local production of CCR5 ligands, which attract $\mathrm{CD}^{+} \mathrm{T}$ cells nearby DC-CD4 conjugates, thus facilitating $\mathrm{T}$ cell help ${ }^{46}$. Chemokines also modulate $\mathrm{T}$ cell response independently of their chemoattractant activities ${ }^{47}$, i.e. they bind DC membranes inducing $\mathrm{T}$ cell adhesion ${ }^{48}$ and may induce DC maturation ${ }^{26-28}$. Our data suggest that chemokines produced during DC presentation of cognate antigen to $\mathrm{CD} 4^{+} \mathrm{T}$ cells may also increase $\mathrm{T}$ cell response by modifying immature DC.

Indeed, at low cell density PTX-pretreated DC are less efficient than untreated DC at inducing T cell activation (Fig. 5). This lower ability of PTX-treated DC to induce T cell activation may be due to their inability to spread (Fig. 6 and 7), thus offering less surface of contact with $\mathrm{T}$ lymphocytes. Alternatively, it may be due to their defective mobility. This decreased activation of $\mathrm{CD}^{+} \mathrm{T}$ cells was not due to "by stander" effect of PTX released in the medium 
on T cells (Fig.5 B and D). Moreover, it was not due to an absence of secretion of chemokines known to attract $\mathrm{T}$ cells, since the same amount of CCL3 and CCL4 was present in supernatants from cocultures of PTX-treated DC or untreated DC with $\mathrm{CD}^{+} \mathrm{T}$ cells and superantigen (data not shown). Finally, it was not related to an inhibitory effect of PTX on DC maturation since PTX-treated DC or untreated DC co-cultured with $\mathrm{T}$ cells and superantigen show a comparable increased expression of CD40, CD80, CD83 and CD86 (Fig. 5C).

Altogether, our data suggest the following model: antigen specific interaction between $\mathrm{CD} 4^{+}$ $\mathrm{T}$ cells and DC induces the secretion of chemokines by both cell types. This will attract more immature DC, providing a source of "fresh" non exhausted DC that still have the ability to capture antigen and produce IL-12. These findings may be physiologically relevant in different settings. First in inflammatory tissue, Ag-specific interactions of memory or effector $\mathrm{T}$ cells with $\mathrm{DC}$ will induce production of chemokines and cytokines that will attract and induce maturation of surrounding or circulating immature DC. These newly recruited DC will capture the Ag (from the environment or from the mature DC) migrate to the draining lymph node and constitute a new pool of Ag-presenting DC. Second, in the secondary lymphoid organs recruitment of some of the numerous resident DC to sites of antigen-specific DC-T cell interaction may be crucial for the inter-DC Ag transfer recently reported ${ }^{38}$. This transfer of $\mathrm{Ag}$ to resident $\mathrm{DC}$ would be induced by $\mathrm{T}$ cell-signals and accompanied by a $\mathrm{T}$ cell dependent maturation of these resident DC that are mostly immature at the steady state ${ }^{49}$. This would in turn increase $\mathrm{T}$ cell activation by amplifying Ag presentation through a larger network of resident DC. Our data are compatible with such a model since as shown herein, chemokines produced by antigen specific DC-CD $4^{+} \mathrm{T}$ cell conjugates induce mobility of DC as well as direct contact between DC potentially enabling transfer of material between DC. Third, even in the absence of Ag transfer between DC, efficient self presentation by newly 
recruited resident DC that will also receive $\mathrm{T}$ cell-derived activation signal may increase the activation of $\mathrm{T}$ cells responding to limiting amount of foreign antigen ${ }^{50}$.

We are currently developing in vivo models to test these hypotheses.

\section{ACKNOWLEDGMENTS}

We thank P. Guermonprez, C. Théry, A.M. Lennon and Stéphanie Hugues for critical reading of the manuscript and/or discussion; François Waharte for assistance with microscopy imaging; E. Labruyère (Institut Pasteur, Paris) for her help with the Dunn Chamber assay.

The authors have no conflicting financial interests.

This work was supported by grants from Institut Curie, INSERM, ARC (Association pour la Recherche contre le Cancer). C. Nobile is a fellow of FRM (Fondation pour la Recherche Medicale).

\section{AUTHORSHIP}

Cinzia Nobile : performed research, analyzed and interpreted data, drafted the manuscript

Marianne Lind : performed research

Francesc Miro : performed research

Karine Chemin : analyzed data

Marie Tourret : performed research

Giovanni Occhipinti : contributed vital new reagents or analytical tools

Stéphanie Dogniaux : performed research

Sebastian Amigorena : analyzed and interpreted data

Claire Hivroz : designed research, analyzed and interpreted data, drafted the manuscript 


\section{REFERENCES:}

1. Banchereau J, Briere F, Caux C, et al. Immunobiology of dendritic cells. Annu Rev Immunol. 2000;18:767-811.

2. Albert ML, Jegathesan M, Darnell RB. Dendritic cell maturation is required for the cross-tolerization of CD8+ T cells. Nat Immunol. 2001;2:1010-1017.

3. Alpan O, Bachelder E, Isil E, Arnheiter H, Matzinger P. 'Educated' dendritic cells act as messengers from memory to naive T helper cells. Nat Immunol. 2004;5:615-622.

4. Caux C, Massacrier C, Vanbervliet B, et al. Activation of human dendritic cells through CD40 cross-linking. J Exp Med. 1994;180:1263-1272.

5. Cella M, Scheidegger D, Palmer-Lehmann K, Lane P, Lanzavecchia A, Alber G. Ligation of CD40 on dendritic cells triggers production of high levels of interleukin-12 and enhances T cell stimulatory capacity: T-T help via APC activation. J Exp Med. 1996;184:747752.

6. Bennett SR, Carbone FR, Karamalis F, Flavell RA, Miller JF, Heath WR. Help for cytotoxic-T-cell responses is mediated by CD40 signalling. Nature. 1998;393:478-480.

7. Schoenberger SP, Toes RE, van der Voort EI, Offringa R, Melief CJ. T-cell help for cytotoxic T lymphocytes is mediated by CD40-CD40L interactions. Nature. 1998;393:480483.

8. Snijders A, Kalinski P, Hilkens CM, Kapsenberg ML. High-level IL-12 production by human dendritic cells requires two signals. Int Immunol. 1998;10:1593-1598.

9. Sporri R, Reis e Sousa C. Newly activated T cells promote maturation of bystander dendritic cells but not IL-12 production. J Immunol. 2003;171:6406-6413.

10. Miro F, Nobile C, Blanchard N, et al. T Cell-Dependent Activation of Dendritic Cells Requires IL-12 and IFN-\{gamma\} Signaling in T Cells. J Immunol. 2006;177:3625-3634. 11. Smith CM, Wilson NS, Waithman J, et al. Cognate CD4(+) T cell licensing of dendritic cells in CD8(+) T cell immunity. Nat Immunol. 2004;5:1143-1148.

12. Randolph GJ, Angeli V, Swartz MA. Dendritic-cell trafficking to lymph nodes through lymphatic vessels. Nat Rev Immunol. 2005;5:617-628.

13. De Smedt T, Pajak B, Muraille E, et al. Regulation of dendritic cell numbers and maturation by lipopolysaccharide in vivo. J Exp Med. 1996;184:1413-1424.

14. Robert C, Fuhlbrigge RC, Kieffer JD, et al. Interaction of dendritic cells with skin endothelium: A new perspective on immunosurveillance. J Exp Med. 1999;189:627-636.

15. Pendl GG, Robert C, Steinert M, et al. Immature mouse dendritic cells enter inflamed tissue, a process that requires E- and P-selectin, but not P-selectin glycoprotein ligand 1. Blood. 2002;99:946-956.

16. Linder S, Hufner K, Wintergerst U, Aepfelbacher M. Microtubule-dependent formation of podosomal adhesion structures in primary human macrophages. J Cell Sci. 2000;113 Pt 23:4165-4176.

17. Zicha D, Dunn GA, Brown AF. A new direct-viewing chemotaxis chamber. J Cell Sci. 1991;99 ( Pt 4):769-775.

18. Benvenuti F, Lagaudriere-Gesbert C, Grandjean I, et al. Dendritic cell maturation controls adhesion, synapse formation, and the duration of the interactions with naive $\mathrm{T}$ lymphocytes. J Immunol. 2004;172:292-301.

19. Sozzani S, Ghezzi S, Iannolo G, et al. Interleukin 10 increases CCR5 expression and HIV infection in human monocytes. J Exp Med. 1998;187:439-444.

20. Scandella E, Men Y, Legler DF, et al. CCL19/CCL21-triggered signal transduction and migration of dendritic cells requires prostaglandin E2. Blood. 2004;103:1595-1601. 
21. Alcami A, Symons JA, Collins PD, Williams TJ, Smith GL. Blockade of chemokine activity by a soluble chemokine binding protein from vaccinia virus. J Immunol. 1998; 160:624-633.

22. Carfi A, Smith CA, Smolak PJ, McGrew J, Wiley DC. Structure of a soluble secreted chemokine inhibitor vCCI (p35) from cowpox virus. Proc Natl Acad Sci U S A. 1999; 96:12379-12383.

23. Dutt P, Wang JF, Groopman JE. Stromal cell-derived factor-1 alpha and stem cell factor/kit ligand share signaling pathways in hemopoietic progenitors: a potential mechanism for cooperative induction of chemotaxis. J Immunol. 1998;161:3652-3658.

24. Calle Y, Burns S, Thrasher AJ, Jones GE. The leukocyte podosome. Eur J Cell Biol. 2006;85:151-157.

25. van Helden SF, Krooshoop DJ, Broers KC, Raymakers RA, Figdor CG, van Leeuwen FN. A critical role for prostaglandin E2 in podosome dissolution and induction of high-speed migration during dendritic cell maturation. J Immunol. 2006;177:1567-1574.

26. Trifilo MJ, Lane TE. The CC chemokine ligand 3 regulates

$\mathrm{CD} 11 \mathrm{c}+\mathrm{CD} 11 \mathrm{~b}+\mathrm{CD} 8 \mathrm{alpha}$ - dendritic cell maturation and activation following viral infection of the central nervous system: implications for a role in T cell activation. Virology.

2004;327:8-15.

27. Marsland BJ, Battig P, Bauer M, et al. CCL19 and CCL21 induce a potent proinflammatory differentiation program in licensed dendritic cells. Immunity. 2005;22:493505.

28. Cappello P, Fraone T, Barberis L, et al. CC-chemokine ligand 16 induces a novel maturation program in human immature monocyte-derived dendritic cells. J Immunol. 2006; 177:6143-6151.

29. West MA, Wallin RP, Matthews SP, et al. Enhanced dendritic cell antigen capture via toll-like receptor-induced actin remodeling. Science. 2004;305:1153-1157.

30. Cyster JG. Chemokines and the homing of dendritic cells to the T cell areas of lymphoid organs. J Exp Med. 1999;189:447-450.

31. Sallusto F, Lanzavecchia A. Understanding dendritic cell and T-lymphocyte traffic through the analysis of chemokine receptor expression. Immunol Rev. 2000;177:134-140.

32. Behrens G, Li M, Smith CM, et al. Helper T cells, dendritic cells and CTL Immunity. Immunol Cell Biol. 2004;82:84-90.

33. de Jong EC, Smits HH, Kapsenberg ML. Dendritic cell-mediated T cell polarization. Springer Semin Immunopathol. 2005;26:289-307.

34. Banchereau J, Steinman RM. Dendritic cells and the control of immunity. Nature. 1998;392:245-252.

35. Sallusto F, Lanzavecchia A. Mobilizing dendritic cells for tolerance, priming, and chronic inflammation. J Exp Med. 1999;189:611-614.

36. Dieu MC, Vanbervliet B, Vicari A, et al. Selective recruitment of immature and mature dendritic cells by distinct chemokines expressed in different anatomic sites. J Exp Med. 1998;188:373-386.

37. Sallusto F, Schaerli P, Loetscher P, et al. Rapid and coordinated switch in chemokine receptor expression during dendritic cell maturation. Eur J Immunol. 1998;28:2760-2769.

38. Allan RS, Waithman J, Bedoui S, et al. Migratory dendritic cells transfer antigen to a lymph node-resident dendritic cell population for efficient CTL priming. Immunity. 2006;25:153-162.

39. Burns S, Thrasher AJ, Blundell MP, Machesky L, Jones GE. Configuration of human dendritic cell cytoskeleton by Rho GTPases, the WAS protein, and differentiation. Blood. 2001;98:1142-1149. 
40. Marchisio PC, Cirillo D, Naldini L, Primavera MV, Teti A, Zambonin-Zallone A. Cell-substratum interaction of cultured avian osteoclasts is mediated by specific adhesion structures. J Cell Biol. 1984;99:1696-1705.

41. Linder S, Aepfelbacher M. Podosomes: adhesion hot-spots of invasive cells. Trends Cell Biol. 2003;13:376-385.

42. Carman CV, Sage PT, Sciuto TE, et al. Transcellular diapedesis is initiated by invasive podosomes. Immunity. 2007;26:784-797.

43. Burns S, Hardy SJ, Buddle J, Yong KL, Jones GE, Thrasher AJ. Maturation of DC is associated with changes in motile characteristics and adherence. Cell Motil Cytoskeleton. 2004;57:118-132.

44. Boes M, Cuvillier A, Ploegh H. Membrane specializations and endosome maturation in dendritic cells and B cells. Trends Cell Biol. 2004;14:175-183.

45. Vogt AB, Spindeldreher S, Kropshofer H. Clustering of MHC-peptide complexes prior to their engagement in the immunological synapse: lipid raft and tetraspan microdomains. Immunol Rev. 2002;189:136-151.

46. Castellino F, Huang AY, Altan-Bonnet G, Stoll S, Scheinecker C, Germain RN. Chemokines enhance immunity by guiding naive CD8+ T cells to sites of CD4+ T celldendritic cell interaction. Nature. 2006;440:890-895.

47. Viola A, Contento RL, Molon B. T cells and their partners: The chemokine dating agency. Trends Immunol. 2006;27:421-427.

48. Friedman RS, Jacobelli J, Krummel MF. Surface-bound chemokines capture and prime T cells for synapse formation. Nat Immunol. 2006;7:1101-1108.

49. McIlroy D, Troadec C, Grassi F, et al. Investigation of human spleen dendritic cell phenotype and distribution reveals evidence of in vivo activation in a subset of organ donors. Blood. 2001;97:3470-3477.

50. Stefanova I, Dorfman JR, Germain RN. Self-recognition promotes the foreign antigen sensitivity of naive T lymphocytes. Nature. 2002;420:429-434. 


\section{LEGENDS}

Figure 1. DC mobility increases after contact with $T$ cells and superantigen (Sag). DC $\left(10^{5}\right)$ were exposed to Sag, and seeded on polylysin-coated coverslips. T cells were added $\left(3 \times 10^{5}\right)$ before image recording. Images were recorded every 3 minutes for 5 hours. (A) Still images taken from web movies 1,2 and $3(\mathrm{DC}+\mathrm{T}$ cells, $\mathrm{DC}+\mathrm{Sag}$, and $\mathrm{DC}+\mathrm{T}+\mathrm{Sag}$, respectively). Arrows point individual DC. Bar, $20 \mu \mathrm{m}$. Right panels, mobility tracks of all DC present in the fields from movies 1, 2, 3 are shown. Results are representative of 3 experiments. (B,C) DC are recruited to the sites of DC-CD4 ${ }^{+} \mathrm{T}$ cells interaction. DC stained with DiD (red) pulsed with TSST1 (+Sag) or left unpulsed (-Sag), were seeded on coverslips together with unpulsed immature CFSE-labeled DC (green) and CD4 ${ }^{+} \mathrm{T}$ cells and cultured for 6h. Cells were then fixed and coverslips mounted for confocal microscopy. (B) Representative images are shown. Bar, $40 \mu \mathrm{m}(\mathbf{C})$ Percentages of DiD-DC in contact with CFSE-DC. Results represent mean \pm SD of 3 independent experiments (30 to 40 conjugates analyzed per experiment). Significance assessed by Student's unpaired t test $\left({ }^{* *} p<0.005\right)$.

Figure 2. Chemokines produced during DC-T cell interactions induce DC chemotaxis. (A,B) DC are seeded on coverslips and exposed to supernatants from $24 \mathrm{~h}$-cocultures of DC+T cells+Superantigens. Videomicroscopy was performed as in Fig.1. (A) Individual frames from web movie 4 and corresponding DC mobility tracks are shown, representative results of 4 experiments. Bar, $20 \mu \mathrm{m}$. (B, C, D) Dunn chamber assay. (B) Migration tracks of DC in a gradient of supernatant from $\mathrm{DC}+\mathrm{T}$ cells + Superantigens (one representative experiment). $\mathrm{DC}$ individual trajectories in the chamber are represented in colors and direction of the gradient is figured with black lines. (C) Mean horizontal and radial velocity of DC. (D) DC trajectories are plotted in a scatter diagram with the starting point for each cell at the intersection between 
the $\mathrm{X}$ and $\mathrm{Y}$ axes, and the direction of the gradient vertical upwards. Left panel: DC exposed to "active" supernatants as in B. Percentage of cells that ended up within a $120^{\circ}$ arc facing the supernatant source is indicated (mean $\pm \mathrm{SD}$ of 3 independent experiments with $\geq 400$ cells tracked). Middle panel: DC exposed to supernatant from $\mathrm{DC}+\mathrm{T}$ cells. Right panel: PTX treated DC exposed to "active" supernatant. (E) Transwell chemotaxis assays. Untreated immature DC or DC treated with PTX (DC $\left.\mathrm{DTX}_{\mathrm{PT}}\right)$ or LPS-treated DC (DCm) were placed in the upper chamber of a transwell, and supernatants from the indicated $24 \mathrm{~h}$-cocultures in the lower chamber. Percentages of DC attracted to the lower chambers after 2 hours are shown. Data are mean $\pm \mathrm{SD}$ of 3 independent experiments.

Figure 3. DC migration is induced by CC-chemokines. (A) Chemokines secreted in the cocultures of DC+T cells with or without TSST1 are quantified by cytometric bead arrays. Each dot represents one donor, mean of chemokine secretion is indicated in each column. (B) CCI inhibits DC migration. DC were pretreated with different concentrations of CCI and migration towards the active supernatant analyzed. Percentages (mean+SD) of neutralization of DC migration is calculated as follows $100-((\%$ of CCI-treated DC in lower chamber/ \% of untreated DC in the lower chamber) X 100).

(C) Percentage of DC attracted towards different recombinant chemokines in transwell chambers are shown. Mean \pm SD of triplicates from one representative experiment.

Figure 4. Production of CC-chemokines by $\mathrm{DC}$ and $\mathrm{CD}^{+} \mathrm{T}$ cells. $\mathrm{DC}$ and $\mathrm{CD} 4^{+} \mathrm{T}$ cells were co-cultured with or without TSST1 (Sag) for 24h. FACS analysis was performed to detect intracellular chemokine production (CCL3, 4 and 5) in DC gated on CD1a expression and $\mathrm{CD}^{+} \mathrm{T}$ cells gated on $\mathrm{CD} 4$ expression. Percentage of $\mathrm{DC}$ or $\mathrm{T}$ cells producing chemokines are indicated in each panel. One representative experiment out of 3. 
Figure 5. Pertussis toxin-treated DC are impaired in the ability to activate $\mathrm{CD}^{+} \mathrm{T}$ cells. (A,B) $4 \times 10^{4} \mathrm{CD}^{+} \mathrm{T}$ cells were incubated with DC, pulsed with $100 \mathrm{ng} / \mathrm{ml}$ of TSST1, pretreated (+ PTX) or not (- PTX) with PTX. CD69 ${ }^{+}$expression on CD4 ${ }^{+}$T cells was analyzed by FACS. (A) Histograms of CD69 expression on $\mathrm{CD}^{+} \mathrm{T}$ cells co-cultured with $\mathrm{DC}$ at a $\mathrm{DC} / \mathrm{T}$ ratio of $1 / 4$ in round or flat bottom wells, $\%$ of $\mathrm{CD} 69^{+} / \mathrm{CD} 4^{+} \mathrm{T}$ cells are indicated. (B) For each $\mathrm{DC} / \mathrm{T}$ cell ratio, data were normalized to the percentage of $\mathrm{CD}^{+} 9^{+} / \mathrm{CD}^{+} \mathrm{T}$ cells obtained in the co-cultures of untreated DC $(=100 \%)$. Mean and SD of 3 experiments. For the indicated ratio, overnight-supernatants from PTX-pretreated DC were added to the co-cultures (grey histograms) (C) Flow cytometric analysis of DC maturation markers in the flat bottom co-cultures. (D) $\mathrm{CD}^{+} \mathrm{T}$ cells were added to the upper chamber of a transwell system together with untreated or PTX-treated DC (DC $\mathrm{PTX})$ and migration towards CXCL12 was analyzed. Significance assessed by Student's unpaired t test. $(* p<0.05 ; * *, p<0.005)$.

Figure 6. Ag specific interactions between $\mathrm{CD}^{+} \mathrm{T}$ cells and DC induce podosome dissolution in DC. (A) Untreated or PTX-treated DC were co-cultured with $\mathrm{CD}^{+} \mathrm{T}$ cells on coverslips in the presence or absence of TSST1. Cells were then fixed and labeled with antivinculin $\mathrm{Ab}$ (green) and phalloidin (red). Bar, $10 \mu \mathrm{m}$. (B) DC presenting podosomes were quantified, plotted to the total number of cells present in the field and presented as $\%$. Mean \pm SD of 4 independent experiments, $\geq 25$ total cells were examined for each condition in each experiment. Significance assessed by Student's unpaired t test. $\left({ }^{*} p<0.05 ; * *, p<0.005\right)$.

Figure 7. Chemokines induce podosome dissolution in DC. (A) Untreated or PTX-treated DC were exposed to the indicated supernatants, or to recombinant chemokines (CCL3, CCL4), and then labeled with anti-vinculin $\mathrm{Ab}$ (green) and phalloidin (red). Bar, $10 \mu \mathrm{m}$. (B, 
C) Cells presenting with podosomes were quantified as in Fig. 6. Mean \pm SEM of 4 independent experiments, $\geq 25$ total cells were examined for each condition in each experiment. Significance assessed by Student's paired t test. (* $p<0.05)$. (D) Flow cytometric analysis of DC maturation markers in response to chemokines. 
A

$D C+S N(D C+T+S a g)$
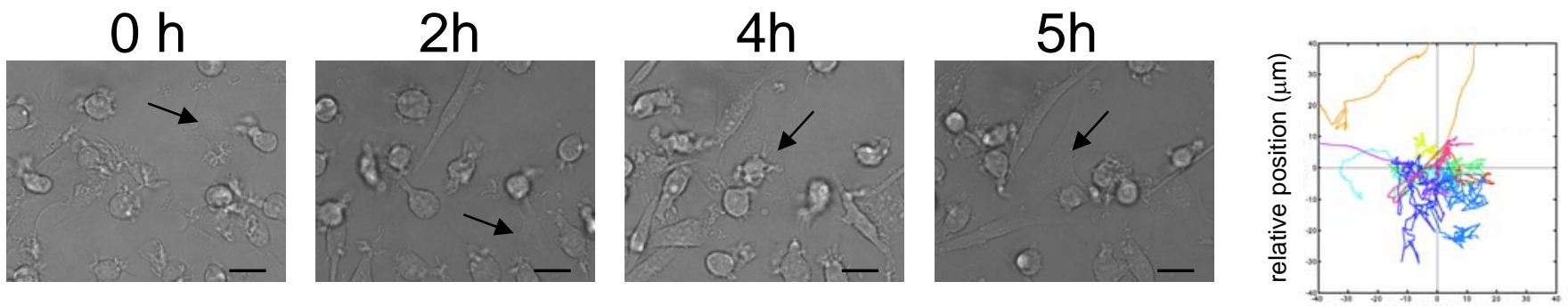

B

C relative position $(\mu \mathrm{m})$
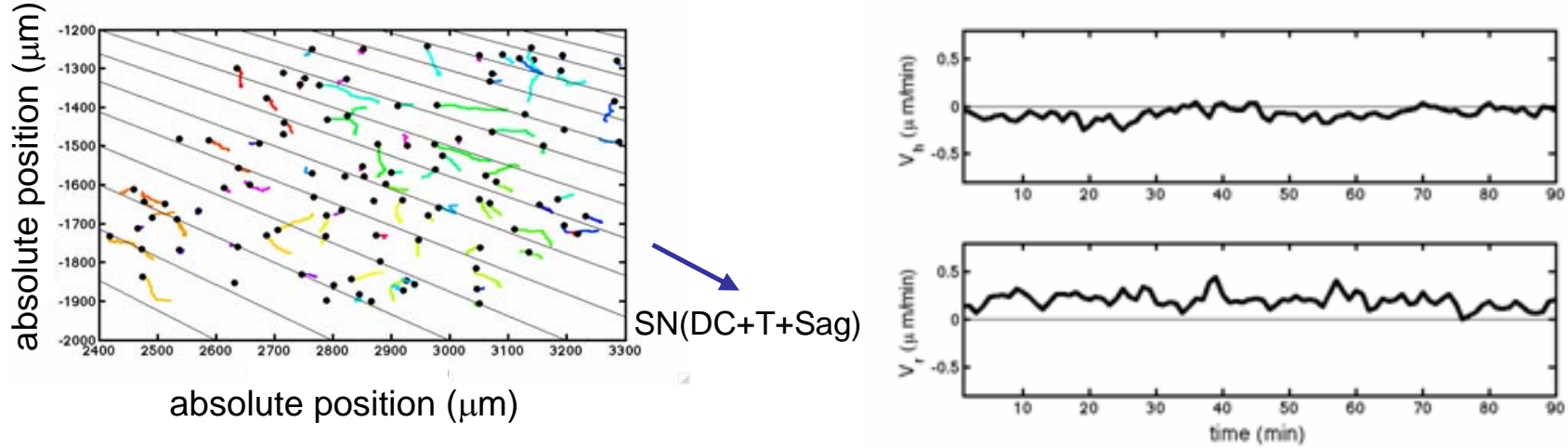

D
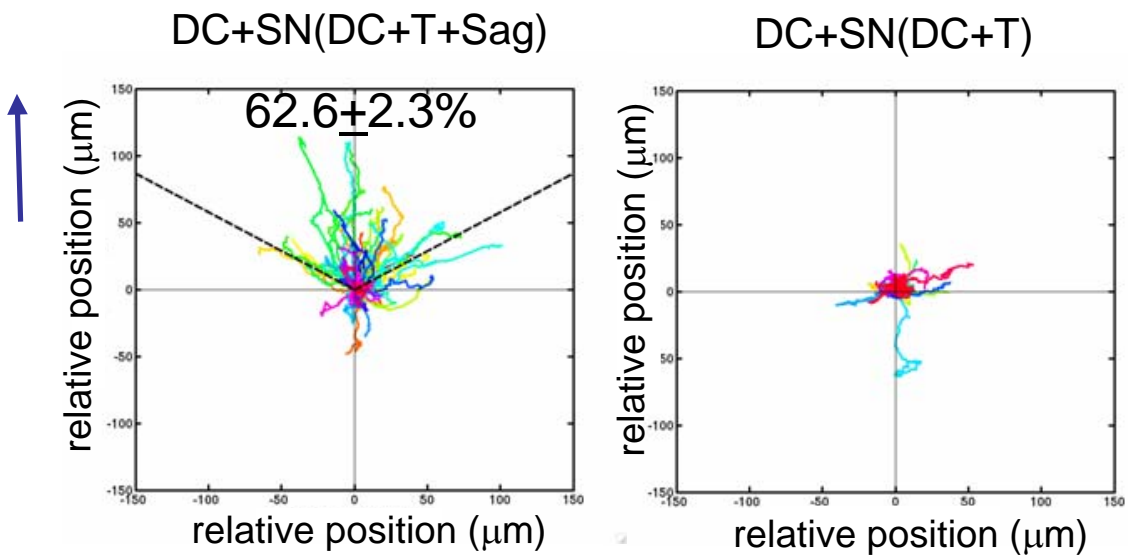

$\mathrm{DCPTX}+\mathrm{SN}(\mathrm{DC}+\mathrm{T}+\mathrm{Sag})$

$E$

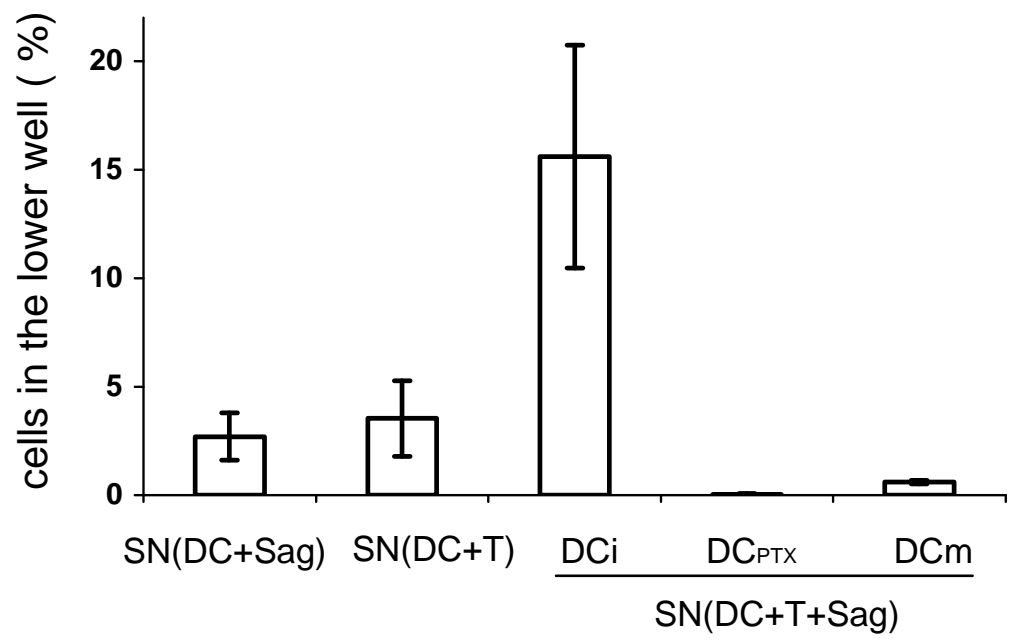

Figure 2

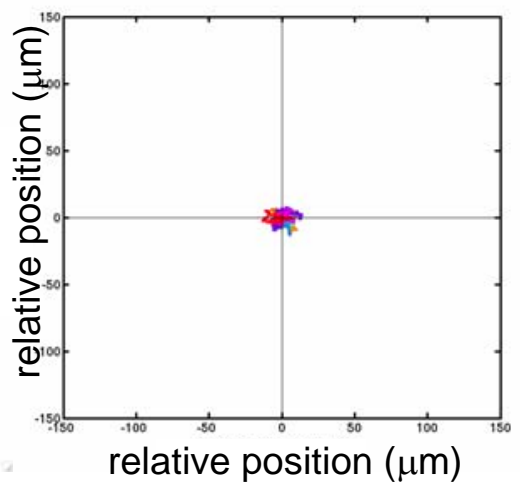


A

flat bottom wells

round bottom wells
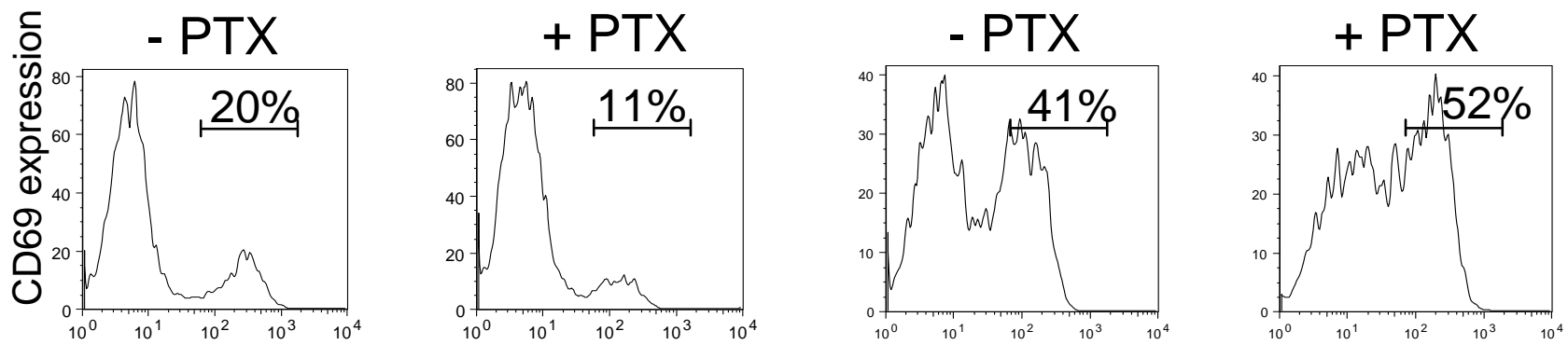

B

Flat

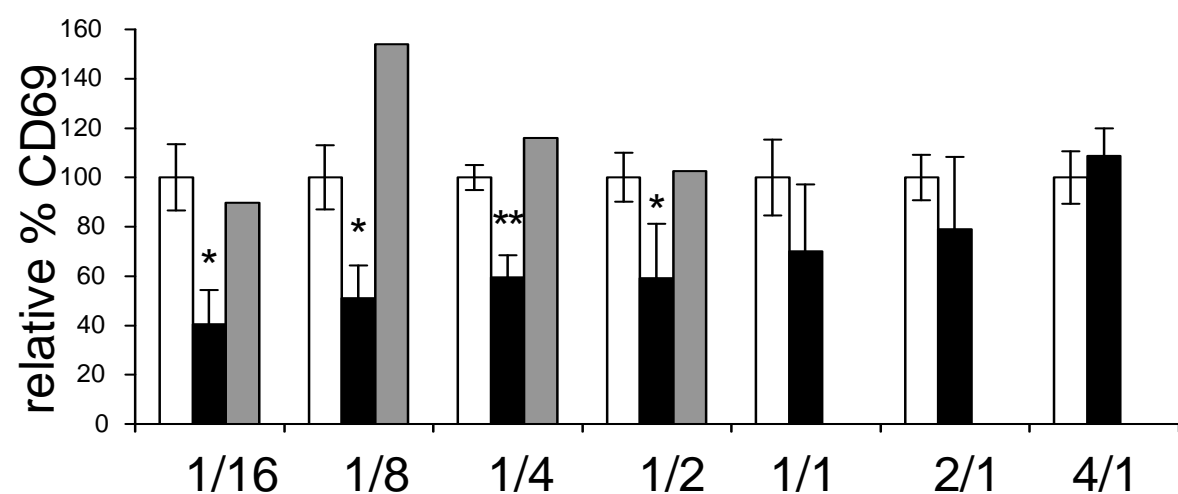

DC/T ratio:

$1 / 16 \quad 1 / 8$

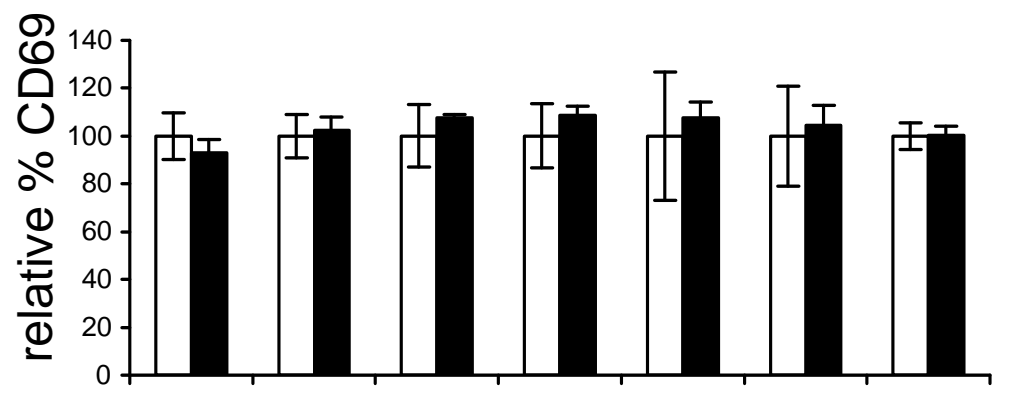

$\mathrm{DC} / \mathrm{T}$ ratio:

$\begin{array}{lllllll}1 / 16 & 1 / 8 & 1 / 4 & 1 / 2 & 1 / 1 & 2 / 1 & 4 / 1\end{array}$

C

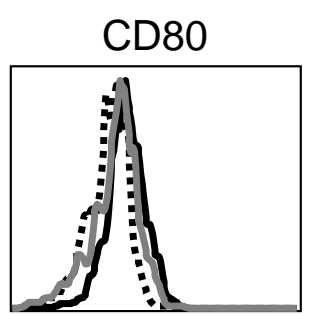

CD86

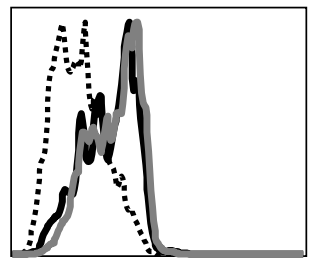

$\because \mathrm{DC}-\mathrm{DC}+\mathrm{T}+\mathrm{SA}=\mathrm{DCPTX}+\mathrm{T}+\mathrm{SA}$
CD83
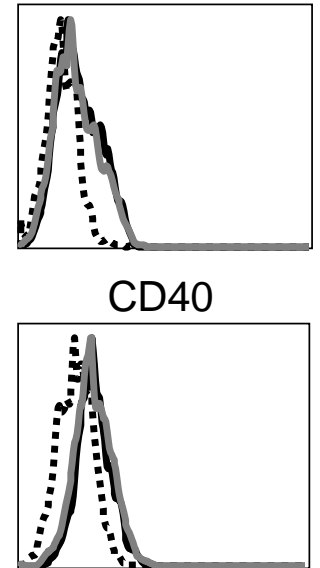

D

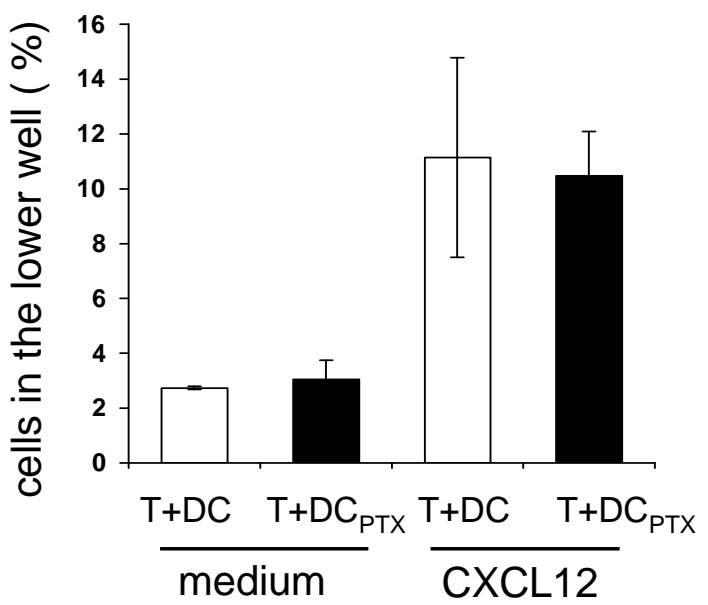


phalloidin
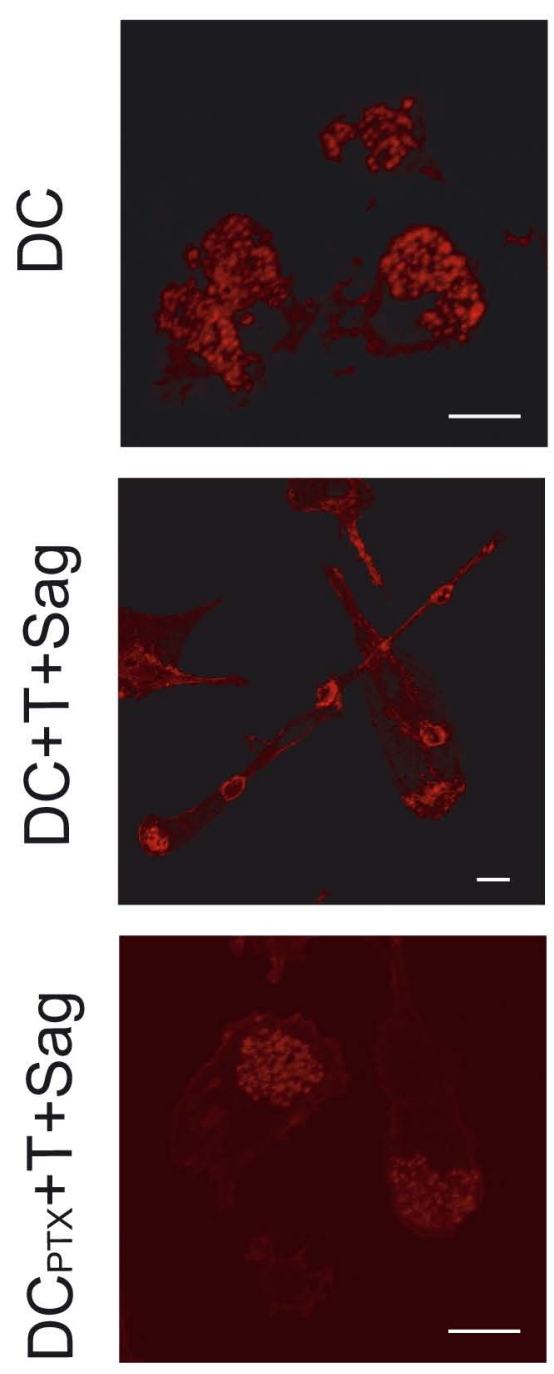

vinculin
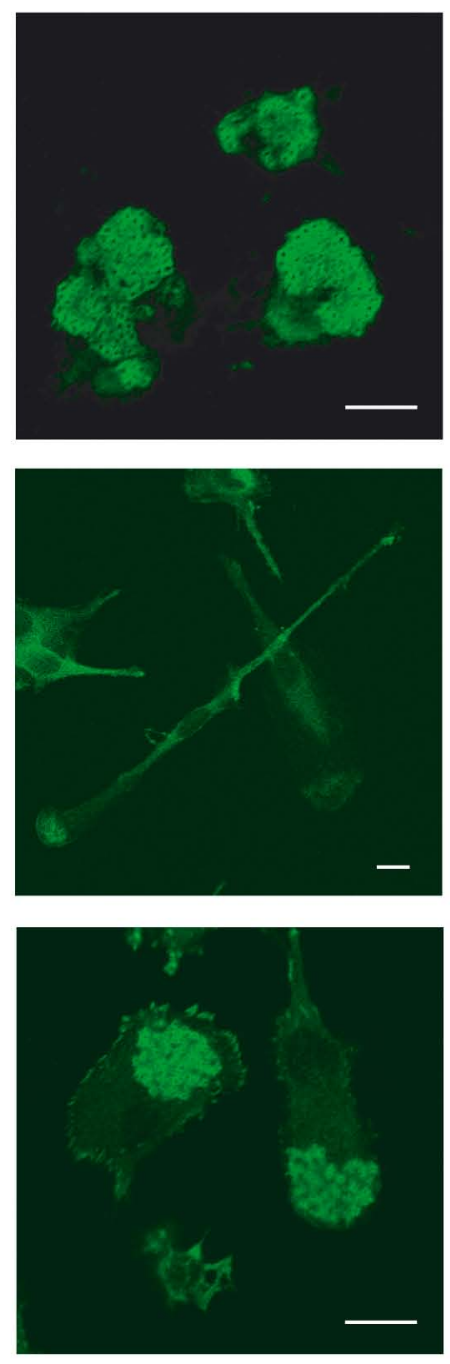

merge
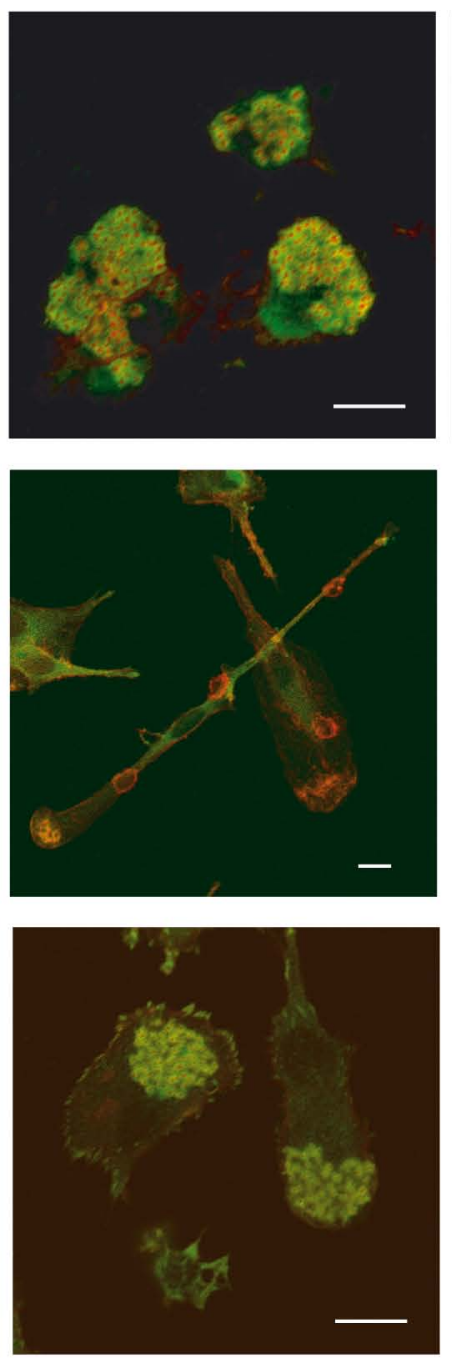

DIC

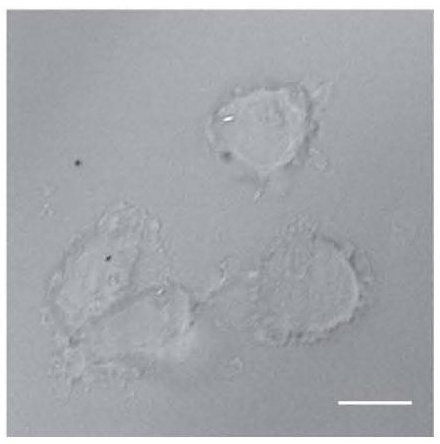

$\mathbf{T}$

$T$

$T$

B

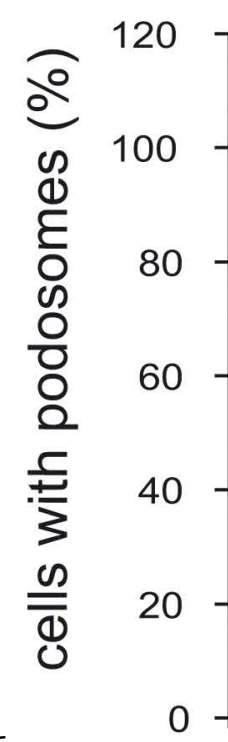

**

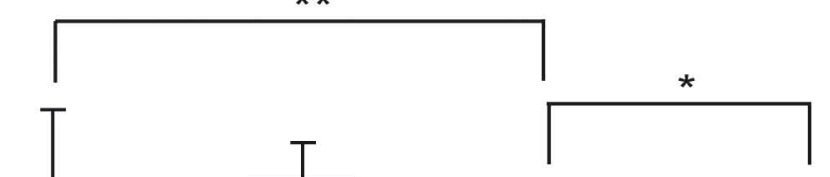

$T$

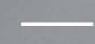
DC
$D C+T \quad D C+T+$ Sag $\quad D C_{P T X}+T+S a g$ 
From www.bloodjournal.org at CALIFORNIA INST TECH/MILLIKAN LIBRARY on January 24, 2008. For personal use only.

phalloidin
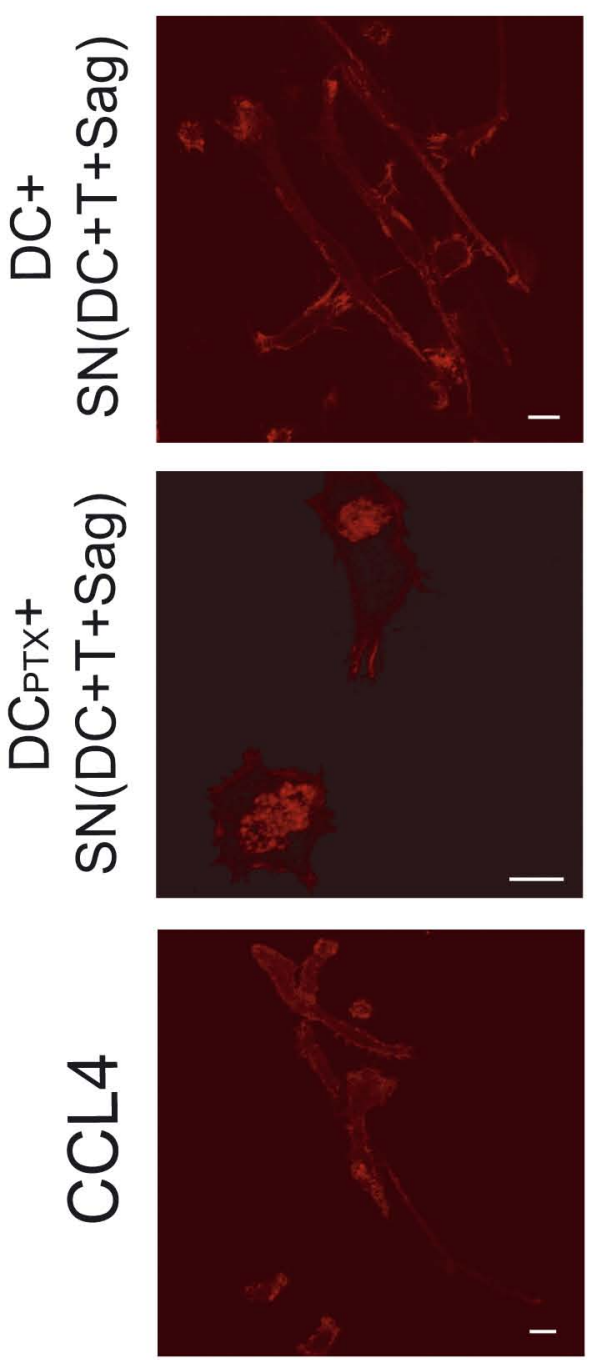

B

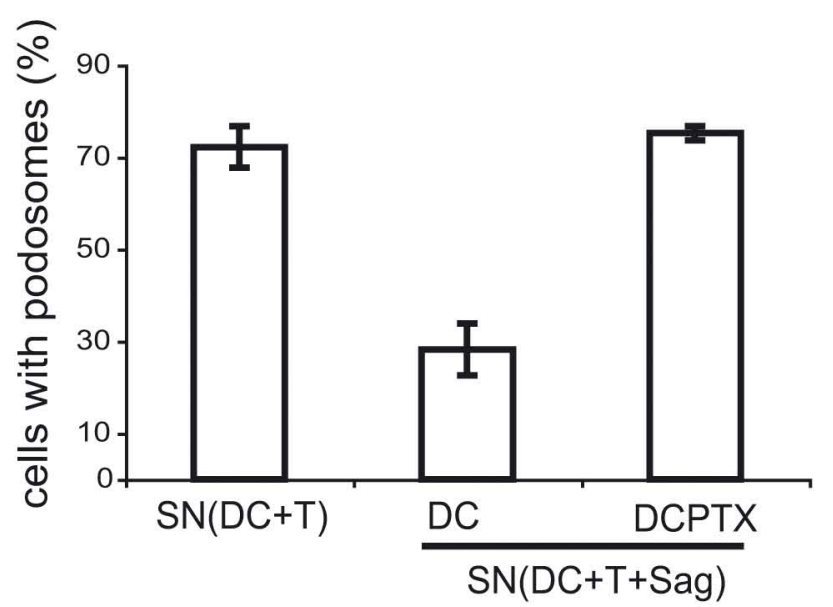

vinculin
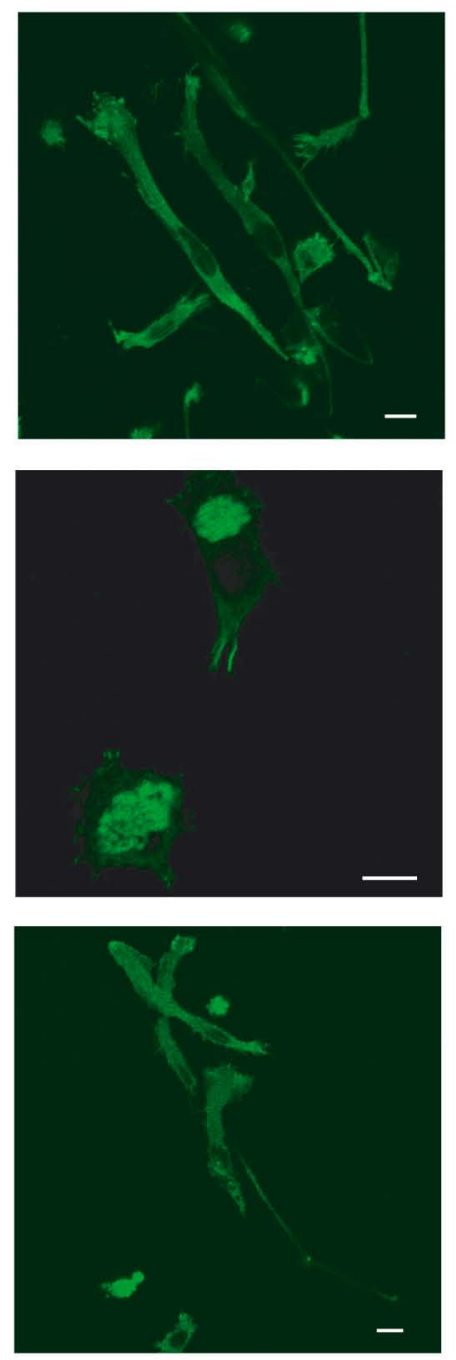

merge
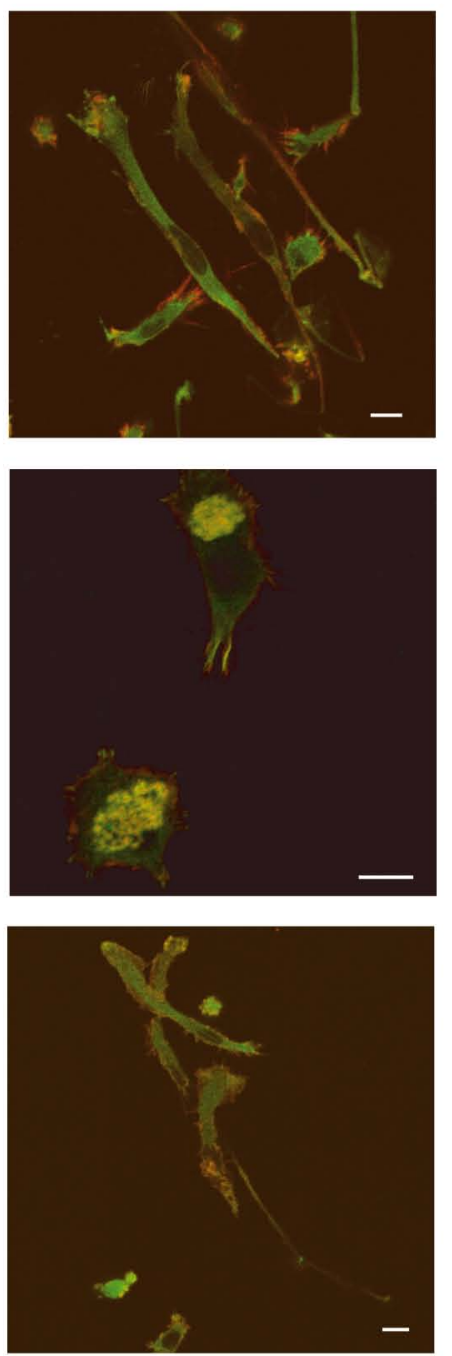

DIC
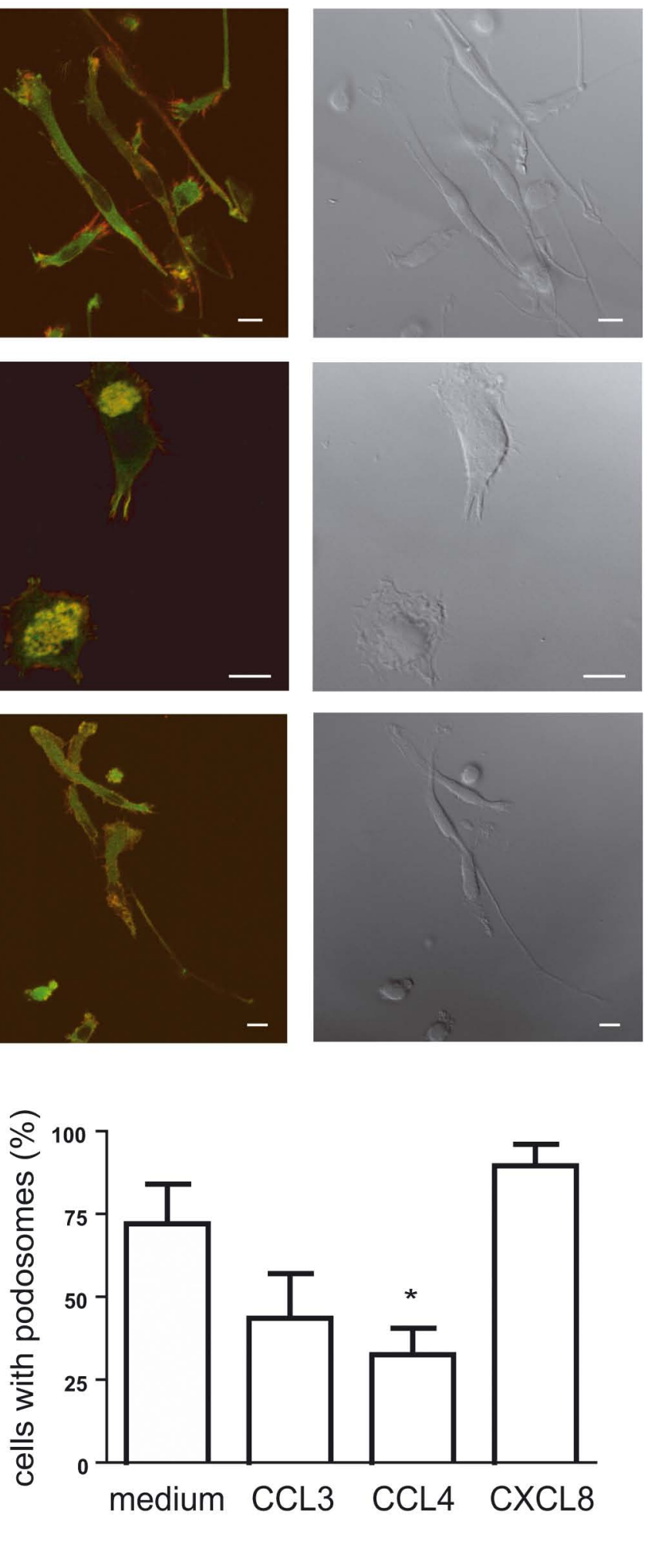

D
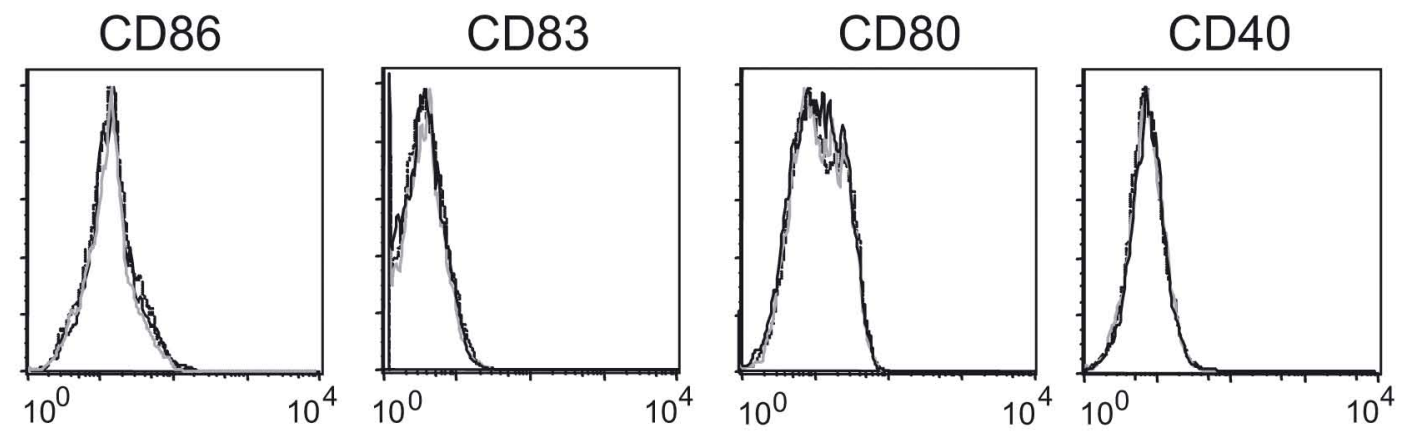

- - - medium

- CCL3

- CCL4 